\title{
Phosphorylation of AMPA-Type Glutamate Receptors by Calcium/ Calmodulin-Dependent Protein Kinase II and Protein Kinase C in Cultured Hippocampal Neurons
}

\author{
Soon-Eng Tan, ${ }^{1}$ Robert J. Wenthold, ${ }^{2}$ and Thomas R. Soderling ${ }^{1}$ \\ 'Vollum Institute, Oregon Health Sciences University, Portland, Oregon 97201 and 2Laboratory of Neurochemistry, \\ National Institute on Deafness and Other Communication Disorders, National Institutes of Health, Bethesda, Maryland \\ 20892
}

Phosphorylation of glutamate receptors (GluRs) is emerging as an important regulatory mechanism. In this study ${ }^{32} \mathrm{P}$ labeling of non-NMDA GluRs was investigated in cultured hippocampal neurons stimulated 2-15 min with agonists that selectively stimulate either $\mathrm{Ca}^{2+} /$ calmodulin-dependent protein kinase II (CaM-kinase II), $\mathrm{Ca}^{2+}$ /phospholipid-dependent protein kinase C (PKC), or CAMP-dependent protein kinase A (PKA). Treatment of hippocampal neurons with glutamate/ glycine (Glu/Gly), ionomycin, or 12-O-tetradecanoylphorbol 13-acetate (TPA) increased ${ }^{32} \mathrm{P}$ labeling of immunoprecipitated $\alpha$-amino-3-hydroxy-5-methyl-4-isoxazoleproprionate (AMPA)-type GluRs by $145 \%, 180 \%$, and $227 \%$, respectively, of control values. This increased phosphorylation of GluRs was predominantly ${ }^{32} \mathrm{P}$-Ser with little ${ }^{32} \mathrm{P}-\mathrm{Th}$ and no detectable ${ }^{32}$ P-Tyr. Glu/Gly and ionomycin, but not TPA, also increased ${ }^{32} \mathrm{P}$ labeling of CaM-kinase II by $175 \%$ and $195 \%$, respectively, of control values. Of these three agonists, only TPA stimulated phosphorylation of MARCKS $(225 \%$ of control), a specific substrate of PKC. Forskolin treatment gave a three- to fourfold increase in the active catalytic subunit of PKA but did not result in the ${ }^{32} P$ labeling of AMPA-type GluRs, CaM-kinase II, or MARCKS. Phosphorylation of GluRs in response to Glu/Gly was blocked by a specific NMDA receptor/ion channel antagonist (DL-2-amino-5-phosphonovaleric acid) or by a cell-permeable inhibitor of CaM-kinase II (1-[N,O-bis(1,5-isoquinolinesulfonyl)- $N$-methyl-L-tyrosyl]4-phenylpiperazine, $\mathrm{KN}-62$ ). These results are consistent with the hypothesis that $\mathrm{Ca}^{2+}$ influx through the NMDA-type ion channel can activate CaM-kinase II, which in turn can phosphorylate and regulate AMPA-type GluR ion channels (McGlade-McCulloh et al., 1993). Such a mechanism could contribute to the postsynaptic component of long-term potentiation and other forms of synaptic plasticity.

[Key words: glutamate receptor, protein kinase, synaptic plasticity, hippocampus, calmodulin-kinase]

\footnotetext{
Received Apr. 30, 1993; revised Aug. 3, 1993; accepted Aug. 4, 1993

We thank Dr. Prabhakar Vissavajjhala for providing the 293 cells expressing GluR1 and GluR3. This work was supported in part by NIH Grant NS27037 (T.R.S.).

Correspondence should be addressed to Thomas R. Soderling, Vollum Institute L 474, Oregon Health Sciences University, 3181 SW Sam Jackson Park Road, Portland, OR 97201 .

Copyright (C) 1994 Society for Neuroscience $0270-6474 / 94 / 141123-07 \$ 05.00 / 0$
}

Glutamate is the major neurotransmitter at excitatory synapses, where it stimulates multiple types of glutamate receptors (GluRs) including non-NMDA receptor/ion channels, NMDA-type ion channels, and metabotropic receptors that are primarily coupled to G-proteins (Gasic and Hollmann, 1992). Non-NMDA receptor/ion channels, which are primarily permeable to $\mathrm{Na}^{+}$and $\mathrm{K}^{+}$, mediate normal rapid synaptic transmission, whereas NMDA-type ion channels, which have additional permeability to $\mathrm{Ca}^{2+}$, are normally inactive due to a voltage-dependent $\mathrm{Mg}^{2+}$ blockage. Some usage-dependent forms of learning and memory, such as long-term potentiation (LTP) in region CAl of hippocampus, require activation of NMDA receptors to allow postsynaptic influx of $\mathrm{Ca}^{2+}$ (Madison et al., 1991). Considerable evidence implicates roles for protein kinases in LTP (Meffert et al., 1991), so it was reasonable to test whether the required $\mathrm{Ca}^{2+}$ influx through the NMDA ion channel involved activation of postsynaptic $\mathrm{Ca}^{2+}$-dependent protein kinases. Indeed, postsynaptic infusion of peptide inhibitors of protein kinase $\mathrm{C}$ (PKC) or $\mathrm{Ca}^{2+} /$ calmodulin-dependent protein kinase II (CaM-kinase II) blocks induction of LTP in hippocampus (Malinow et al., 1989). Furthermore, mice that lack the $\alpha$ isoform of CaM-kinase II, the major protein in the postsynaptic density (PSD) of these glutaminergic synapses (Kennedy et al., 1983), are deficient in hippocampal LTP (Silva et al., 1992a) and another form of hippocampal learning, the Morris water test (Silva et al., 1992b). Thus, considerable evidence implicates involvement of CaMkinase II in learning and memory (Soderling, 1993).

Over the past several years we have attempted to provide a molecular understanding for possible involvement of CaM-kinase II in models of synaptic plasticity such as LTP. We have focused on two questions: (1) does $\mathrm{Ca}^{2+}$ influx through the NMDA receptor, as required for initiation of LTP, result in activation of CaM-kinase II, and (2) does activated CaM-kinase II phosphorylate and regulate non-NMDA GluRs? Regulation of GluRs by CaM-kinase II is of particular interest since the $\mathrm{Ca}^{2+} / \mathrm{CaM}$-activated kinase rapidly autophosphorylates, thereby generating a constitutively active, $\mathrm{Ca}^{2+-}$-independent kinase (Colbran and Soderling, 1990; Hanson and Schulman, 1992) that may act as a molecular sensor of synaptic frequency (Lisman, 1989). We have demonstrated that treatment of cultured cerebellar granule cells (Fukunaga et al., 1989, 1990) or hippocampal neurons (Fukunaga et al., 1992) with glutamate/glycine (Glu/Gly) activates CaM-kinase II through autophosphorylation and generation of the $\mathrm{Ca}^{2+}$-independent form. This activation of CaM-kinase II by Glu/Gly was blocked by specific 
NMDA antagonists. We have also investigated phosphorylation and regulation of GluRs by CaM-kinase II and have focused on the non-NMDA, $\alpha$-amino-3-hydroxy-5-methyl-4-isoxazoleproprionate (AMPA)-type ion channels (GluR 1-GluR4) for the following reason. Data over the past several years indicate both presynaptic and postsynaptic components for the increased synaptic efficacy during expression of LTP. The presynaptic aspect appears to involve increased release of glutamate (Bekkers and Stevens, 1990), whereas the postsynaptic component is due to increased responsiveness of GluRs (Davies et al., 1989). This enhanced postsynaptic responsiveness presumably involves nonNMDA GluRs as non-NMDA antagonists, but not NMDA antagonists, block the expression of LTP (Madison et al., 1991). Since many ion channels are regulated by protein phosphorylation, and CaM-kinase II and GluRs are colocalized in the PSDs of glutaminergic synapses, we have investigated the phosphorylation of isolated AMPA-type GluRs by CaM-kinase II and other protein kinases. GluR 1 expressed using the baculovirus/ $\mathrm{Sf} 9$ cell system was strongly phosphorylated in vitro by purified CaM-kinase II, weakly phosphorylated by $\mathrm{PKC}$, and not phosphorylated by protein kinase A (PKA) (McGlade-McCulloh et al., 1993). AMPA-type GluRs in isolated synaptosomes or PSDs from rat forebrain were also strongly phosphorylated by the CaM-kinase II endogenous to those preparations. This phosphorylation of AMPA-type GluRs by CaM-kinase II appears to have a strong regulatory effect since introduction of activated CaM-kinase II into cultured hippocampal neurons enhanced kainate-induced ion current three- to fourfold (McGladeMcCulloh et al., 1993). In light of these results, it was important to investigate whether activation of CaM-kinase II in cultured hippocampal neurons, particularly through stimulation of NMDA receptors, results in increased phosphorylation of AMP $\Lambda$-type GluRs. Other protein kinases, particularly PKA, have also been shown to have regulatory effects on non-NMDA GluRs (Greengard et al., 1991; Wang et al., 1991, 1993; Keller et al., 1992; Raymond et al., 1993), so effects of PKA and PKC activation were also studied.

\section{Materials and Methods}

Materials. The following chemicals and reagents were purchased from the indicated sources. Fetal calf serum, horse serum, trypsin, trypsin inhibitor, minimum essential medium, and microcystin-LR, GIBCO/ Bethesda Research Labs; poly-L-lysine, transferrin, putrescine, sodium selenite, triiodothyronine, progesterone, corticosterone, insulin, cytosine- $\beta$-arabinofuranoside, $\mathrm{L}$-glutamate, glycine, cAMP, kemptide, phosphoserine, phosphothreonine, and phosphotyrosine, Sigma Co.; ${ }^{32} \mathrm{P}$. orthophosphate, ICN; $\gamma$-32P-ATP, DuPont-New England Nuclear; ionomycin, $O$-tetradecanoylphorbol 13-acetate (TPA), and forskolin, Calbiochem; PKI-tide (PKA peptide inhibitor) and $\mathrm{PKC}_{19-36}$ peptide, Peninsula Laboratories; 1 -[ $N, O$-bis( 1,5 -isoquinolinesulfonyl $)-N$-methyl-L-tyrosyl]-4-phenylpiperazine (KN-62), Seikagaku; DL-2-amino-5phosphonovaleric acid (AP5), Cambridge Research Biochemicals; protein-A-Sepharose CL-4B and GammaBind G-Sepharose, Pharmacia LKB Biotechnology; anti-MARCK antiserum was a gift from Dr. Blackshear at Duke University. Other supplies were commercially available and were used at the condition specified by the manufacturer.

Cell culture. Hippocampal primary cultures were prepared from newborn pups (Sprague-Dawley, Simmerson, CA), according to the method of Lester et al. (1989). The hippocampal cells were seeded at a density of $2 \times 10^{6}$ cells per $35 \mathrm{~mm}$ tissue culture dishes (Falcon) that were precoated with poly-L-lysine. After $24 \mathrm{hr}$, cells were treated with $10 \mu \mathrm{M}$ cytosine- $\beta$-arabinofuranoside to stop non-neuronal cell replication. The culture medium was replaced with fresh growth medium without fetal calf serum at 4 and $7 \mathrm{~d}$ of culture. The cells were maintained in a $37^{\circ} \mathrm{C}$ humidified incubator with $95 \%$ air and $5 \% \mathrm{CO}_{2}$.

In situ ${ }^{32} P$ labeling. Ten-day-old cultures were maintained in phos- phate-free minimum essential medium for $12 \mathrm{hr}$ before ${ }^{3} \mathrm{PO}_{4}(1 \mathrm{mCi} /$ $\mathrm{ml}$ ) labeling for $1 \mathrm{hr}$. The cells were then preincubated for $30 \mathrm{~min}$ in Kreb-Ringer HEPES buffer (KRH) without calcium as described (Fukunaga et al., 1992). In some experiments KN-62 or AP5 was also present during this preincubation. For those experiments containing $\mathrm{KN}-62$, the experimental and control incubations contained $0.3 \%$ dimethyl sulfoxide as solvent. Cells were stimulated with the indicated agonist in $\mathrm{KRH}$ containing $2.7 \mathrm{mM} \mathrm{CaCl}_{2}$ but without magnesium (Fukunaga et al., 1992). After stimulation, KRH was aspirated, RIPA buffer [50 m Tris- $\mathrm{HCl}, 150 \mathrm{~mm} \mathrm{NaCl}, 10 \mathrm{~mm}$ EDTA, 2 mM EGTA, $15 \mathrm{~mm}$ NaPPi, $50 \mathrm{~mm} \mathrm{NaF}, 100 \mathrm{~mm} \beta$-glycerophosphate, $0.5 \mu$ m microcystin, $0.1 \%$ SDS, $1 \% \mathrm{NP}-40$, plus $20 \mu \mathrm{g} / \mathrm{ml}$ soybean trypsin inhibitor, $5 \mu \mathrm{g} /$ $\mathrm{ml}$ leupeptin, $5 \mu \mathrm{g} / \mathrm{ml}$ aprotinin, and $1 \mathrm{~mm}$ phenylmethylsulfonyl fluoride (PMSF), pH 7.5] was added, and the cells were frozen in liquid nitrogen.

Immunoprecipitation and quantification of ${ }^{32} P$-labeled proteins. Cells were thawed and scraped into a $1.5 \mathrm{ml}$ microcentrifuge tube. The lysates were centrifuged, and the supernatants were saved for immunoprecipitation experiments. Five microliters of the samples were TCA (trichloroacetic acid) precipitated, dissolved in $0.1 \mathrm{~N} \mathrm{NaOH}$, and reprecipitated with TCA. Total radioactivity was equated for the samples before the immunoprecipitation. Immunoprecipitations were performed in duplicate or triplicate for each condition. Supernatants were precleared with normal nonimmune serum followed by precipitation with protein-A-Sepharose CL-4B (PAS). The supernatant was then transferred to a new tube and incubated with specific antiserum for either CaM-kinase II, GluR1, or myristoylated alanine-rich C kinase substrate (MARCKS) for $16 \mathrm{hr}$ at $4^{\circ} \mathrm{C}$. Protein-A-Sepharose was added for $30 \mathrm{~min}$. The $\mathrm{P} \Lambda \mathrm{S}$-antibody-antigen complexes were pelleted and washed four times with $50 \mathrm{~mm}$ Tris- $\mathrm{HCl}(\mathrm{pH} 8.3), 0.6 \mathrm{~m} \mathrm{NaCl}, 0.5 \%$ Triton X-100 plus 0.1 mM PMSF. GammaBind-G-Sepharose was used for the immunoprecipitation using anti-CaM-kinase II antiserum since the antiserum was obtained from goat. Immunoprecipitates were solubilized in SDS sample buffer followed by boiling for $2 \mathrm{~min}$. Proteins were fractionated by SDS-PAGE (Laemmli, 1970), and phosphoproteins were visualized by autoradiography. The ${ }^{32} \mathrm{P}$ incorporation was quantified by densitometric scanning (Bio-Rad).

Immunoblotting. After SDS-PAGE, the proteins were transferred onto polyvinylidene difluoride membrane (Immobilon, Millipore). The membrane was blocked with $5 \%$ nonfat milk in $25 \mathrm{~mm}$ Tris- $\mathrm{HCl} \mathrm{pH}$ $7.5,150 \mathrm{~mm} \mathrm{NaCl}, 0.2 \%$ Tween-20 for $2 \mathrm{hr}$ at room temperature. The blot was then rinsed in buffer (without milk) and incubated with GluR 1 antiserum for $1 \mathrm{hr}$. $\Lambda$ fter another rinse, the blot was incubated with horseradish peroxidase-conjugated donkey anti-rabbit IgG for $30 \mathrm{~min}$. The protein bands recognized by antibody were visualized by the chemiluminescence method (ECL, Amersham).

Phosphoamino acid analysis. The AMPA-type ${ }^{32} \mathrm{P}-\mathrm{GluR}$ transferred from SDS-PAGE to Immobilon membrane was cut out and washed with methanol followed by water for several hours. The blot was then subjected to acid hydrolysis in $20 \mu$ of $6 \mathrm{~N} \mathrm{HCl}$ at $110^{\circ} \mathrm{C}$ for $1 \mathrm{hr}$. After centrifugation, the sample was dried using a Speed-Vac concentrator (Savant) and solubilized with $5 \mu \mathrm{l}$ of aqueous buffer containing $1 \mathrm{mg} /$ $\mathrm{ml}$ each of phosphoserine, phosphothreonine, and phosphotyrosine. These samples were then spotted on a cellulose plate (EM Chemicals) and subjected to electrophoresis at $1.5 \mathrm{kV}$ for $45 \mathrm{~min}$ using $\mathrm{pH} 3.5$ buffer (glacial acetic acid, pyridine, water, 5:0.5:94.5, v/v/v). Standards were detected by ninhydrin staining, whereas the radiolabeled samples were visualized by autoradiography.

In vitro kinase assays. After agonist treatment, cells were aspirated and suspended at $5^{\circ} \mathrm{C}$ in $0.3 \mathrm{ml}$ of $10 \mathrm{~mm}$ polassium phosphate $(\mathrm{pH}$ 6.8), $10 \mathrm{~mm}$ EDTA, $0.5 \mathrm{~mm}$ 1-methyl-3-isobutylxanthine (IBMX) plus $0.1 \mathrm{~mm}$ leupeptin, $5 \mu \mathrm{g} / \mathrm{ml}$ aprotinin, $75 \mu \mathrm{M}$ pepstatin $\mathrm{A}$, and $1 \mathrm{~mm}$ dithiothreitol to determine the activation ratio of PKA (Soderling et al., 1973). After sonication the insoluble fraction was removed by centrifugation at $13,000 \times g$ for $5 \mathrm{~min}$. The PKA reaction mixture contained $10 \mathrm{~mm}$ potassium phosphate $(\mathrm{pH} 6.8), 10 \mathrm{~mm}$ magnesium acetate, 1 mM EGTA, 0.4 mM $\gamma^{-32}$ P-ATP (1000-2000 cpm/pmol), $60 \mu \mathrm{M}$ kemptide, with or without $1 \mu \mathrm{M}$ cAMP in a volume of $25 \mu 1$. For determining CaM-kinase II activation the cells were suspended in $0.3 \mathrm{ml}$ of $50 \mathrm{mM}$ HEPES (pH 7.5), 10 mm EDTA, 4 mM EGTA, 15 mm sodium pyrophosphate, $25 \mathrm{~mm} \mathrm{NaF}, 100 \mathrm{~mm} \beta$-glycerophosphate, $0.5 \mu \mathrm{M}$ microcystin, $0.1 \%$ Triton X-100, plus $75 \mu \mathrm{M}$ pepstatin $\mathrm{A}, 5 \mu \mathrm{g} / \mathrm{ml}$ leupeptin, and $5 \mu \mathrm{g} / \mathrm{ml}$ aprotinin (Fukunaga et al., 1992). Cells were sonicated and centrifuged as for PKA. The CaM-kinase II activities were measured using syntide-2 as the substrate (Hashimoto and Soderling, 1987). The 
standard kinase assay contained $50 \mathrm{~mm}$ HEPES ( $\mathrm{pH} 7.5$ ), $10 \mathrm{~mm}$ magnesium acetate, $0.4 \mathrm{mM} \gamma-{ }^{32} \mathrm{P}-\mathrm{ATP}(1000-2000 \mathrm{cpm} / \mathrm{pmol}), 40 \mu \mathrm{M}$ syntide-2, $2 \mu \mathrm{M}$ PKC inhibitor peptide, and $5 \mu \mathrm{M}$ PKI-tide in a volume of $25 \mu \mathrm{l}$. To measure total CaM-kinase II activity, the reaction mixture contained $0.5 \mathrm{~mm} \mathrm{CaCl}, 2 \mu \mathrm{M}$ CaM. For $\mathrm{Ca}^{2+}$-independent kinase activity, 1 mM EGTA was present during the assay. All kinase reactions were initiated by addition of cell extract. After incubating at $30^{\circ} \mathrm{C}$ for $3 \mathrm{~min}$, a $15 \mu \mathrm{l}$ aliquot was spotted on a P-cellulose paper, which was washed and counted by liquid scintillation counter (Roskoski, 1985).

Other methods. The cDNAs for GluR1 and GluR3, kindly provided by Drs. Hollmann and Heinemann, were inserted into a Friend spleen focus-forming virus $5^{\prime}$ long terminal repeat expression plasmid (Fuhlbrigge et al., 1988). Transformed human embryonic kidney (293) cells were transiently transfected with these plasmids and lysed $60 \mathrm{hr}$ later.

Two-dimensional peptide mapping of the tryptic digest of ${ }^{32} \mathrm{P}-\mathrm{GluR}$ isolated from Glu/Gly-stimulated cells was performed as described previously (McGlade-McCulloh et al., 1993) using the Hunter Thin Layer Electrophoresis system (HTLE-7000, CBS Scientific Co.). Electrophoresis was performed for $50 \mathrm{~min}$ at $1 \mathrm{kV}$, and chromatography was for $16 \mathrm{hr}$ using $n$-butanol, pyridine, acetic acid, and water in volume ratios of $0.375: 0.25: 0.075: 0.30$.

\section{Results and Discussion}

The expression of AMPA-type GluRs and CaM-kinase II in cultures of hippocampal neurons was assessed by Western analysis and kinase assays, respectively. CaM-kinase II activity increased with time of culturing up to a maximum of $20 \cdot \mathrm{nmol} /$ $\mathrm{min} / \mathrm{mg}$ at $10 \mathrm{~d}$. AMPA-type GluR immunoreactivity also increased with time of culture up to $8 \mathrm{~d}$ in culture (not shown). We therefore chose to maintain our cells for $10 \mathrm{~d}$ in culture prior to use. At this time about $30 \%$ of the cells were nonneuronal as determined by comparing immunohistochemical staining with anti-glial fibrillary acidic protein antibody to staining with GluRI antibody (not shown). It has been previously shown in these cultured cells that almost all the immunoreactive CaM-kinase II is localized to the neurons (Fukunaga et al., 1992). Therefore, the ${ }^{32} \mathrm{P}$ labeling of GluRs by CaM-kinase II is occurring almost exclusively in the neurons.

This study employs immunoprecipitation of AMPA-type ${ }^{32} \mathrm{P}-$ GluRs using an antibody against a synthetic peptide corresponding to the extreme $\mathrm{COOH}$ terminus of GluR1 (Ab7 of Wenthold et al., 1992). A previous characterization of this GluR1 Ab7 has shown by Western analysis of GluR1-GluR4 expressed in COS cells that the antibody is specific for GluR1. However, Ab7 coimmunoprecipitates all four subunits from solubilized rat brain membranes (Wenthold et al., 1992), indicating that native AMPA-type GluRs are heteromeric complexes of GluR1-GluR4. Coprecipitation of all four GluR subunits depends on the specific immunoprecipitation conditions. In our previous study of GluR phosphorylation in isolated rat synaptosomes and PSDs (McGlade-McCulloh et al., 1993), these preparations were solubilized with $1 \%$ SDS, which was then diluted 10 -fold with RIPA buffer prior to immunoprecipitation. Under those conditions, $\mathrm{Ab} 7$ immunoprecipitates were not immunoreactive (S. E. Tan, unpublished observation) using an antibody against GluR2/3 (Ab25 of Wenthold et al., 1992). In the present study our immunoprecipitation conditions are slightly different than in the two previous studies, so it was necessary to establish which GluR subunits were immunoprecipitated by GluR1 Ab7. Figure 1 shows that $\mathrm{Ab} 7$ immunoprecipitates from the hippocampal cell extract give strong immunoreactivity on Western analysis to GluR1 Ab7 (Fig. 1A, lane 1) and to GluR2/3 Ab25 (Fig. 1B, lane 1). Lanes 2 and 3 confirm the specificities of these two antibodies using extracts from kidney 293 cells expressing either GluR1 (lane 2) or GluR3 (lane 3). Thus, our present

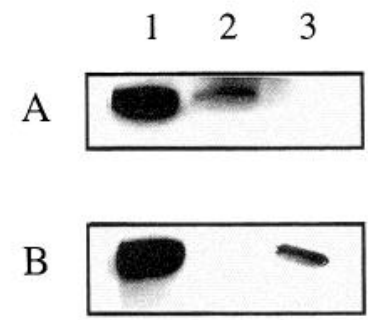

Figure 1. Western blot analysis of immunoprecipitation and specificity of GluR1 antibody. Immunoprecipitates of hippocampal cell extract (lane $1 ; 25 \mu \mathrm{l})$ or aliquots $(20 \mu \mathrm{g})$ of kidney 293 cells expressing GluR 1 (lane 2) or GluR3 (lane 3) were subjected to SDS-PAGE and Western blot analysis using antibody to GluR $1(A)$ or antibody to GluR2/3 (B). The region of the autoradiograph containing the GluRs was scanned with a Nikon film scanner and converted into a digital image, which was transferred to a composite graphics program.

conditions give immunoprecipitation of the heteromeric GluR complex containing at least GluR $1-3$. We did not specifically test for coimmunoprecipitation of GluR4, but since GluR4 is part of the heteromeric complex immunoprecipitated by $\mathrm{Ab} 7$ (Wenthold et al., 1992), we probably are also coprecipitating GluR1-GluR4. However, it should be noted that hippocampus contains very little GluR4 compared to GluR1-GluR3 (Petralia and Wenthold, 1992).

Our previous study has shown that CaM-kinase II is a strong catalyst for in vitro phosphorylation of GluR1 (McGladeMcCulloh et al., 1993) and that treatment of hippocampal neurons with Glu/Gly activates CaM-kinase II by stimulation of NMDA receptors with resultant $\mathrm{Ca}^{2+}$ influx (Fukunaga et al., 1992). We also demonstrated that activated CaM-kinase II can enhance AMPA-type GluR ion current in hippocampal neurons (McGlade-McCulloh et al., 1993). The next logical step was to examine whether Glu/Gly treatment of hippocampal neurons increased phosphorylation of AMPA-type GluRs through activation of CaM-kinase II. For purposes of comparison, we also wanted to activate selectively CaM-kinase II, PKC, or PKA using other agonists and chose ionomycin, TPA, and forskolin, respectively, for this purpose. We had previously shown (Fukunaga et al., 1992) that $30 \mathrm{~min}$ preincubation of the hippocampal neurons in $\mathrm{KRH}$ buffer without $\mathrm{Ca}^{2+}$ reduced the $\mathrm{Ca}^{2+}$ independent activation state of CaM-kinase II from a basal value of $5-6 \%$ to $1-2 \%$. Upon addition of $\mathrm{Ca}^{2+}(2.7 \mathrm{~mm})$ alone, the kinase immediately returned to its basal $5-6 \% \mathrm{Ca}^{2+}$ independence. We therefore used this treatment paradigm in the present study. Glu/Gly were used as coactivators of the NMDA ion channel in the absence of extracellular $\mathrm{Mg}^{2+}$ to avoid voltage-dependent $\mathrm{Mg}^{2+}$ blockage (Gasic and Hollmann, 1992). Initial time course studies (not shown) were performed to determine optimal times for ${ }^{32} \mathrm{P}$ labeling of GluRs by the various agonists.

Figure 2 illustrates data from a single experiment on the ${ }^{32} \mathrm{P}$ labeling of several proteins in response to Glu/Gly or TPA treatment. In this experiment Glu/Gly $\left(10 \mu \mathrm{M} / 1 \mu_{\mathrm{M}}\right.$ for $\left.5 \mathrm{~min}\right)$ increased phosphorylation of AMPA-type GluRs and of CaMkinase II with no effect on MARCKS, the myristoylated alaninerich C kinase substrate (McIllroy et al., 1991). TPA (1 $\mu \mathrm{M}$ for $15 \mathrm{~min}$ ) increased phosphorylation of GluRs and MARCKS protein with no effect on phosphorylation of CaM-kinase II. Analysis of ${ }^{32} \mathrm{P}$ labeling of proteins by this approach involves multiple steps that are subject to experimental variability, so in 
Figure 2. Phosphorylation of AMPAtype GluRs, CaM-kinase II, and MARCKS by Glu/Gly and TPA stimulation in cultured hippocampal neurons. Cultured hippocampal neurons were labeled with ${ }^{32} \mathrm{PO}_{4}(1 \mathrm{mCi} / \mathrm{ml})$ for $1 \mathrm{hr}$ and preincubated as detailed in Materials and Methods. Cells were then stimulated with $10 \mu \mathrm{M} \mathrm{Glu} / 1 \mu \mathrm{M}$ Gly or $1 \mu \mathrm{M}$ TPA in KRH buffer containing $2.7 \mathrm{mM} \mathrm{CaCl}_{2}$ but no $\mathrm{MgCl}_{2}$. Medium was aspirated from the cells, RIPA buffer was added, and the cell suspension was quick frozen, thawed, and immunoprecipitated with the appropriate antiserum (see Materials and Methods for details). All the data are from the same experiment. Each panel illustrates the appropriate region of the SDS-PAGE autoradiograph for the indicated protein from duplicate immunoprecipitations. Glu/Gly $(10 \mu \mathrm{M} / 1 \mu \mathrm{M})$ treatment was for $5 \mathrm{~min}$; TPA $(1 \mu \mathrm{M})$ was for 15 min. Autoradiographs were scanned as in Figure 1.
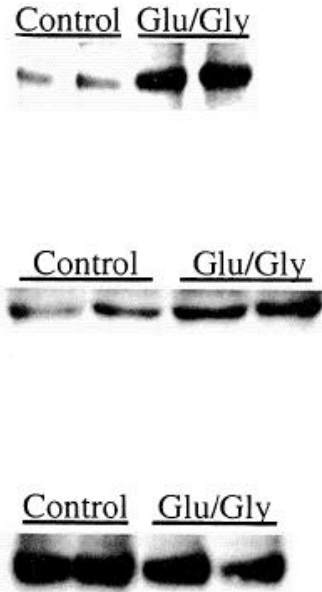

GluRs

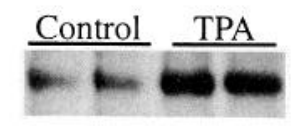

CaMKII

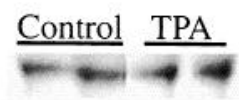

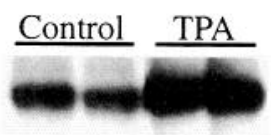

each experiment immunoprecipitations were done in duplicate or triplicate. Figure 3 show a composite graph from a number of separate experiments that permits statistical analysis of the data. Glu/Gly increased phosphorylation of GluRs to $145 \pm$ $10 \%(p<0.005)$ and of CaM-kinase II to $175 \pm 21 \%(p<$ 0.005 ) of control values. Ionomycin, a divalent cation ionophore, gave a similar response by increasing GluR and CaMkinase II phosphorylations to $180 \pm 25 \%(p<0.001)$ and 195 $\pm 22 \%(p<0.001)$, respectively, of controls. GluR and MARCKS protein phosphorylations were enhanced to $227 \pm 27 \%$ and 168 $\pm 7 \%$ of controls, respectively, by TPA treatment. When ${ }^{32} \mathrm{P}$ GluRs from control, Glu/Gly, and TPA treatments were excised from the gels of two experiments and analyzed for ${ }^{32} \mathrm{P}$-amino acid contents, the average distribution between ${ }^{32} \mathrm{P}-\mathrm{Ser}$ and ${ }^{32} \mathrm{P}$ $\mathrm{Thr}$, respectively, was as follows: control, $60 \%, 40 \%$; Glu/Gly, $68 \%, 32 \%$; and TPA, $73 \%, 27 \%$. This indicates that $80-90 \%$ of the increased phosphorylation of GluRs in response to Glu/Gly or TPA was on Ser. This is consistent with the fact that the consensus CaM-kinase II (Ser 627, numberings based on GluR1) and PKC (Ser 650, 658, and 676) phosphorylation sites on the intracellular loop of GluR1-GluR4 are predominantly serines (Keinänen et al., 1990; Egebjerg et al., 1991). We did not detect any ${ }^{32} \mathrm{P}-\mathrm{Ty}$ in spite of the fact that NMDA receptor stimulation can activate tyrosine kinases (Bading and Greenberg, 1991) and that GluR 1 expressed in kidney 293 cells was phosphorylated on Tyr by coexpressed v-src tyrosine kinase (Moss et al., 1993).

The above results suggest that AMPA-type GluR phosphorylation in response to stimulation by Glu/Gly or ionomycin is due to CaM-kinase II activation, whereas the TPA effect is mediated by PKC. Although more complicated scenarios can be postulated, the data would tend to exclude them. For example, ionomycin and Glu/Gly might be expected to activate PKC, and, in fact, we have demonstrated that the Glu/Gly treatment does give translocation of PKC from the cytosol to the membrane fraction (Fukunaga et al., 1992). However, this translocation was very transient in that it was maximal at about $15 \mathrm{sec}$ and had returned to the basal value within $2 \mathrm{~min}$. The fact that MARCKS protein was not phosphorylated in response to either Glu/Gly (5 min) or ionomycin (2 min) (Fig. 3) also indicates that PKC activation was certainly minimal. Scholz and Palfrey observed very transient phosphorylation of MARCKS that was elevated at $30 \mathrm{sec}$ but not at $2 \mathrm{~min}$ after glutamate treatment of hippocampal neurons (Scholz and Palfrey, 1991). Another possibility is that TPA activation of PKC with MARCKS phosphorylation could result in release of CaM, which would activate CaM-kinase II (MacNicol and Schulman, 1992). MARCKS binds CaM in a $\mathrm{Ca}^{2+}$-independent manner, and phosphorylation of MARCKS by PKC promotes release of CaM (McIlroy et al., 1991). This mechanism does not appear to underlie the TPA effect on GluR phosphorylation since TPA does not increase the ${ }^{32} \mathrm{P}$ labeling of CaM-kinase II (Fig. 3). This conclusion is substantiated in Figure 4, where the activation state of CaM-kinase II was measured. Since CaM-kinase II contains multiple autophosphorylation sites, only one of which regulates generation of $\mathrm{Ca}^{2+}$-independent activity (Colbran and Soderling, 1990; Hanson and Schulman, 1992), measurement of $\mathrm{Ca}^{2+}$-independent activity is probably a more sensitive index of CaM-kinase II activation. Figure 4 (left) shows that although Glu/Gly and ionomycin both increase $\mathrm{Ca}^{2+}$-independent CaMkinase II, TPA has little if any effect. Figure 4 (right) verifies that forskolin treatment of the hippocampal neurons strongly activated PKA even though it had no effect on phosphorylation of AMPA-type GluR.

Although the data of Figure 3 suggest that the Glu/Gly enhancement of AMPA-type GluR phosphorylation was mediated by activation of CaM-kinase II, we wanted to test this hypothesis further. For this purpose we used KN-62, a cell-permeable inhibitor of the CaM-kinase family. KN-62 inhibits CaM-kinase II competitively with $\mathrm{Ca}^{2+} / \mathrm{CaM}$, so it has no inhibitory effect on PKC or PKA (Hidaka and Kobayoshi, 1992). It also shows little or no inhibition in vitro (Hidaka and Kobayoshi, 1992) or in cultured smooth muscle cells (Tansey et al., 1992) toward myosin light chain kinase, another $\mathrm{Ca}^{2+} / \mathrm{CaM}$-dependent protein kinase. Preincubation of hippocampal neurons with $10 \mu \mathrm{M}$ $\mathrm{KN}-62$ reduced basal phosphorylation of both GluR and CaMkinase II and blocked the stimulatory response to Glu/Gly (Fig. 5 , top) but not the response to TPA (not shown). This is very strong evidence that the enhanced phosphorylation of AMPA- 


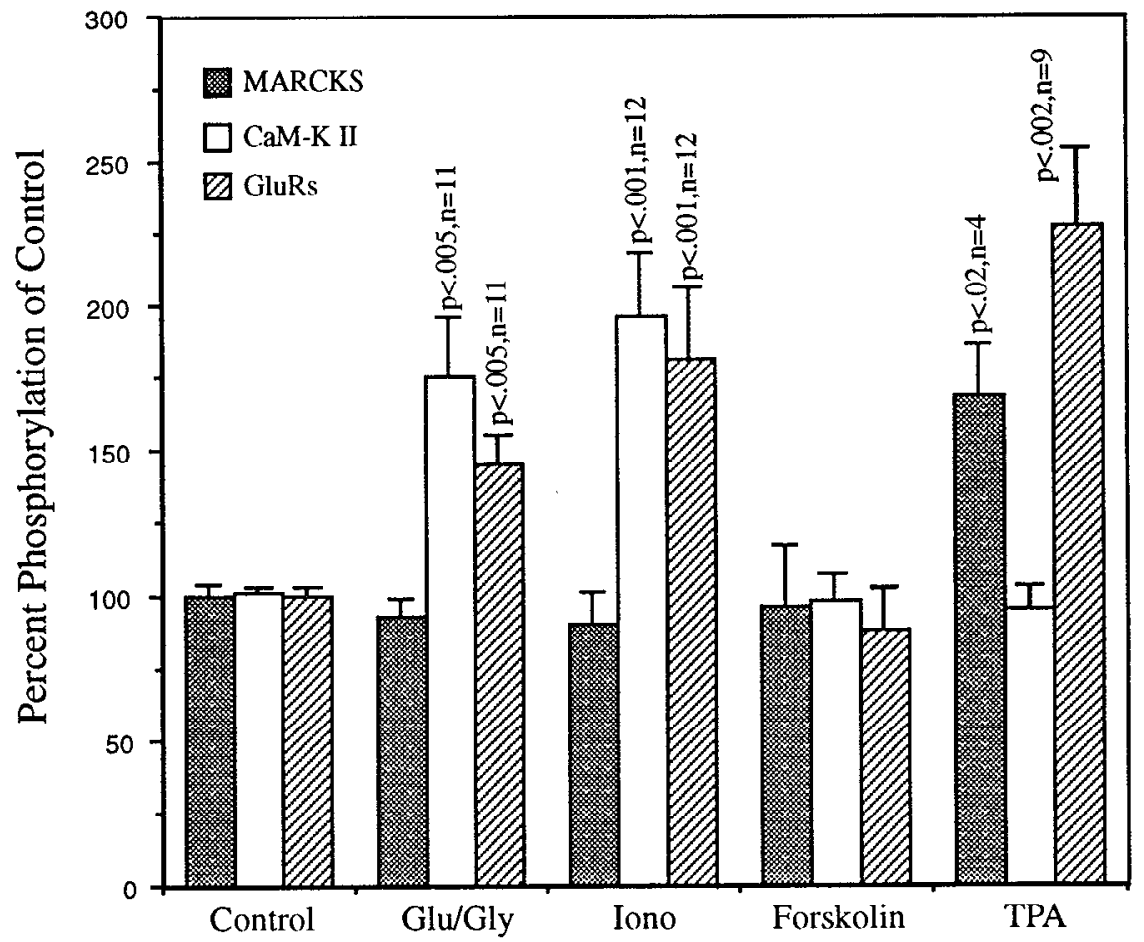

Figure 3. Effects of agonists on ${ }^{32} \mathrm{P}$ labeling in cultured hippocampal neurons. Autoradiographs from many experiments were quantitated relative to the appropriate control using a Bio- $\mathrm{Rad}$ scanning densitometer. Controls contained the appropriate solvents used for each agonist. Experimental treatments were as follows: Glu/Gly, $10 \mu \mathbf{M} / 1 \mu \mathbf{M}$, for $5 \mathrm{~min}$; ionomycin, $5 \mu \mathrm{M}$, for $2 \mathrm{~min}$; forskolin, $10 \mu \mathrm{M}$, for $15 \mathrm{~min}$; TPA, 1 $\mu \mathrm{M}$, for $15 \mathrm{~min}$. Data are given as mean $\pm \mathrm{SE}$, and statistical analysis was performed using the Student's $t$ test.

type GluR by Glu/Gly treatment is mediated by CaM-kinase activation. Since CaM-kinase II is by far the most prominent member of the CaM-kinase family, especially in hippocampus, where CaM-kinase II constitutes up to $2 \%$ of total protein (Erondu and Kennedy, 1985) and is the Inajor PSD protein (Kennedy et al., 1983), the Glu/Gly response is probably mediated by CaM-kinase II. Further evidence for this conclusion is the fact that the two-dimensional peptide map of GluR phosphorylated in response to Glu/Gly (Fig. 6) is similar if not identical to the peptide map of GluR 1 phosphorylated in vitro by CaM-kinase II (see Fig. $1 b$ of McGlade-McCulloh, 1993). Additionally, we have shown that activation of CaM-kinase II by Glu/Gly is through stimulation of the NMDA receptor and $\mathrm{Ca}^{2+}$ influx (Fukunaga et al., 1992). The transient PKC translocation is not due to NMDA receptor activation, but it appears to require stimulation of the metabotropic GluR (Fukunaga et al., 1992), which is coupled to phospholipase $\mathrm{C}$ activation (Gasic and Hollmann, 1992). Since the phosphorylation of AMPA-type GluR
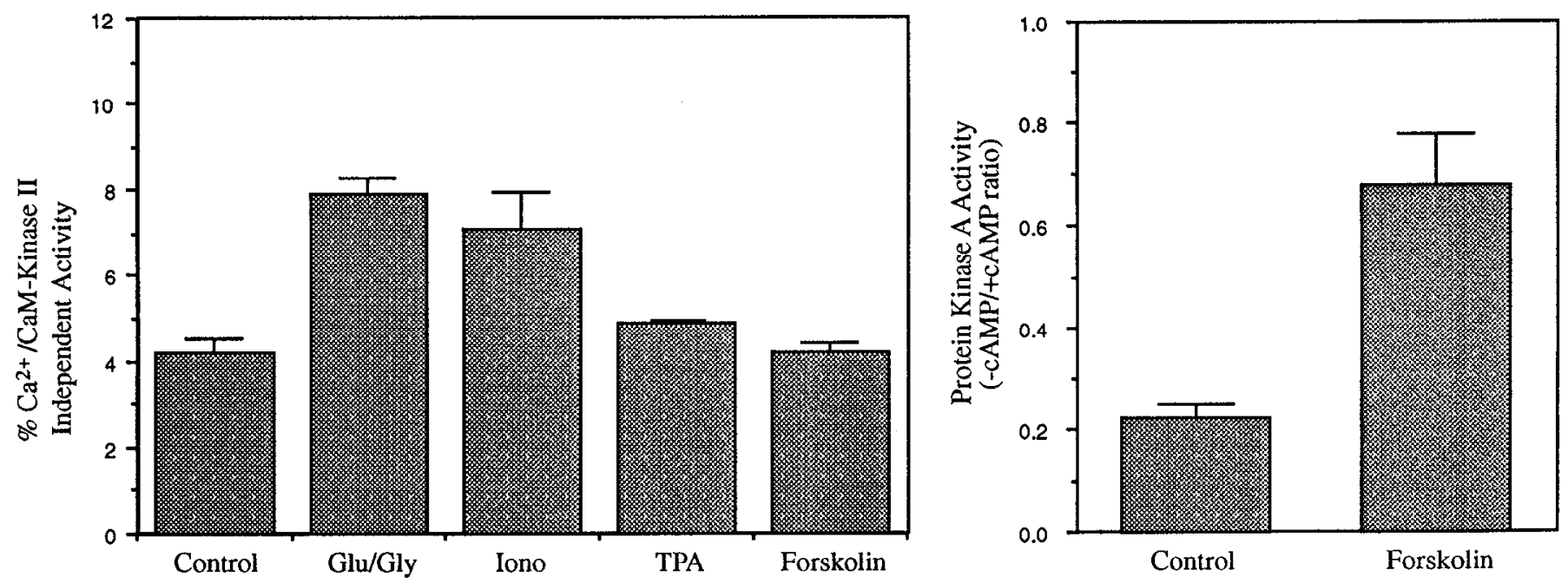

Figure 4. Activation of CaM-kinase II and PKA. Cultured hippocampal neurons were treated identically to experiments in which ${ }^{32} \mathrm{P}$ labeling was measured except the cells were not metabolically labeled. Cells were stimulated with Glu/Gly (10 $\mu \mathrm{M} / 1 \mu \mathrm{M}, 5 \mathrm{~min})$, ionomycin $(5 \mu \mathrm{M}, 2 \mathrm{~min})$, TPA $(1 \mu \mathrm{M}, 15 \mathrm{~min})$, or forskolin $(10 \mu \mathrm{M}, 15 \mathrm{~min})$. For the graph to the left the cells were homogenized in CaM-kinase II homogenization buffer (see Materials and Methods) and assayed for CaM-kinase II activity using syntide-2 as substrate in the presence of EGTA (Ca ${ }^{2+}$-independent activity) or $\mathrm{Ca}^{2+} / \mathrm{CaM}$ (total activity). The ratios of these two activities times 100 gives the percentage of $\mathrm{Ca}^{2+}$-independent activity. For the graph to the right the cells were homogenized in $10 \mathrm{~mm}$ potassium phosphate (pH 6.8), $10 \mathrm{mM}$ EDTA, $0.5 \mathrm{mM}$ IBMX and assayed for PKA activity using kemptide as substrate in the absence and presence of cAMP. The ratio of these two activities gives the fraction of PKA in the active catalytic subunit (Soderling et al., 1973). See Materials and Methods for exact conditions of protein kinase assays. Data are given as mean \pm SE, $n=3$. The SE for the TPA effect is too small (0.03) to show on the plot. 


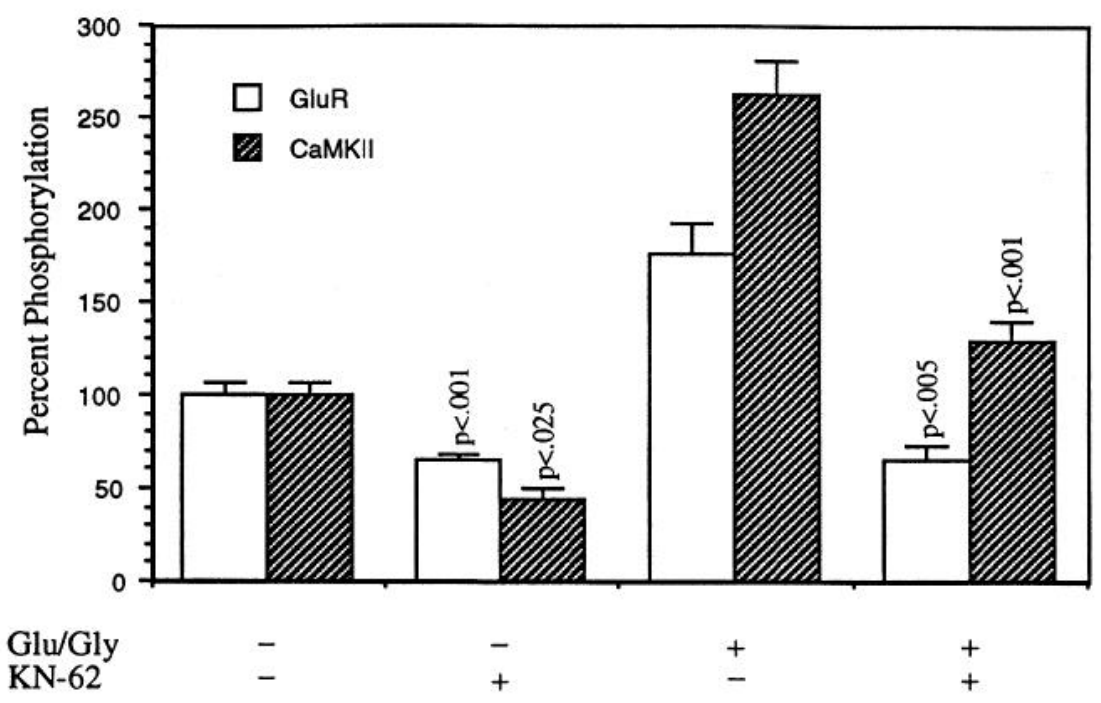

Figure 5. Inhibition of AMPA-type GluR phosphorylation by an NMDA antagonist (AP5) or CaM-kinase inhibitor (KN-62). ${ }^{32} \mathrm{P}$-labeled hippocampal neurons were preincubated for $30 \mathrm{~min}$ without (-) or with (+) $10 \mu \mathrm{M} \mathrm{KN}-62$ (top) or $100 \mu \mathrm{M}$ AP5 (bottom) as indicated prior to stimulation for $5 \mathrm{~min}$ with Glu/Gly as in Figure 2. Data were analyzed as in Figure 4 and are given as mean $\pm \mathrm{SE}$.

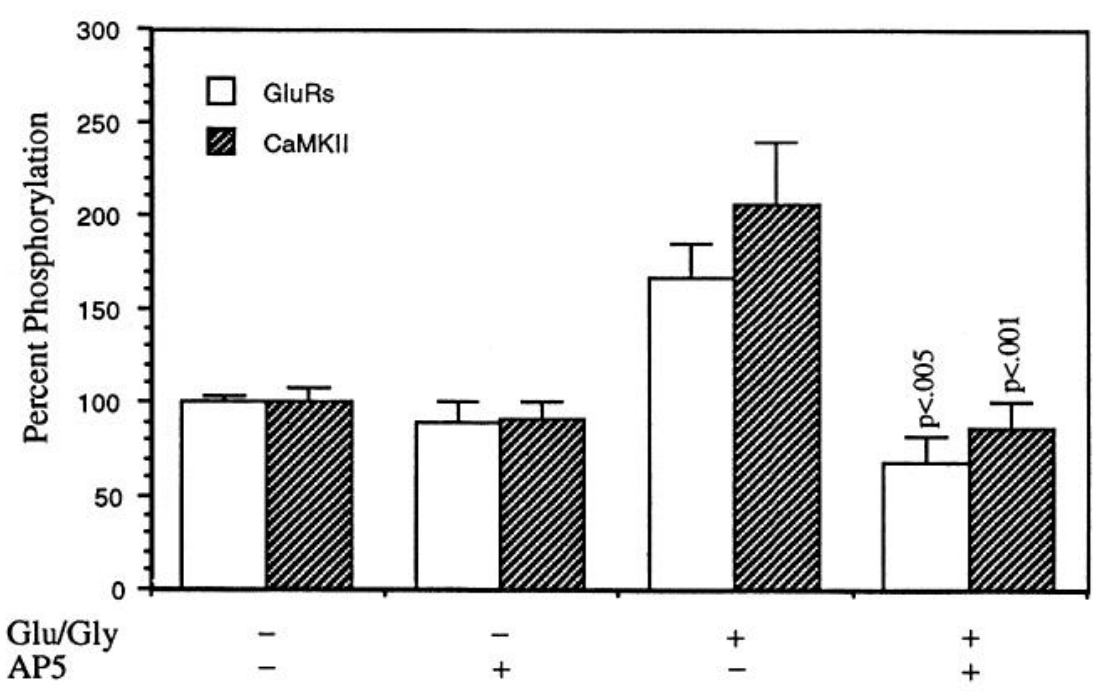

by Glu/Gly is completely blocked by the NMDA antagonist AP5 (Fig. 5, bottom), this further supports the conclusion that CaM-kinase II is involved in this response.

The above experiments confirm and extend our previous study using in vitro preparations that showed CaM-kinase II and PKC, but not PKA, could phosphorylate GluR1 (McGlade-McCulloh et al., 1993). This is consistent with the presence of consensus phosphorylation sites for CaM-kinase II and PKC, but not PKA, on the major intracellular loop of GluR1-GluR4 (Keinänen et al., 1990; Egebjerg et al., 1991). PKC appears to be a much stronger catalyst, compared to CaM-kinase II, of AMPA-type GluR phosphorylation in the cultured hippocampal neurons than it was of GluR1 phosphorylation in vitro (McGladeMcCulloh et al., 1993). Possible reasons could be that other GluR subunits (i.e., GluR2-GluR4) may contain better PKC phosphorylation sites than GluR1, or PKC isoforms in hippocampal cells are better catalysts than the $\alpha$ isoform used in vitro. It should be noted that although PKA does not directly phosphorylate AMPA-type GluRs, it does enhance non-NMDA ion current in hippocampal neurons (Greengard et al., 1991; Wang et al., 1991), perhaps through phosphorylation of GluR6 (Ray-
Figure 6. Peptide map of AMPA-type GluR phosphorylated in response to Glu/Gly. Hippocampal cells wcre labeled and stimulated with Glu/Gly, and the immunoprecipitated ${ }^{32} \mathrm{P}-\mathrm{GluR}$ was run on SDS-PAGE as in Figure 2. The radioactive GluR band was excised from the gel, digested with trypsin, and subjected to two-dimensional peptide mapping. The arrow marks the origin. 
mond el al., 1993; Wang et al., 1993). The mechanism whereby PKA enhances kainate current in oocytes expressing GluR 1 and GluR3 (Keller et al., 1992) is unclear. Although phosphorylation of a regulatory protein associated with GluRs is a possibility, evidence for a regulatory protein that coimmunoprecipitates with AMPA-type GluRs is lacking (Wenthold et al., 1992). Another possibility would be inhibition of phosphatase 1 by PKAmediated phosphorylation of inhibitor 1 (Huang and Glinsmann, 1976).

The data of Figures 3 and 5 demonstrate that NMDA receptor stimulation in hippocampal neurons results in activation of CaMkinase II, which in turn phosphorylates AMPA-type GluRs. Combined with our previous demonstration that infusion of activated CaM-kinase II into hippocampal neurons results in enhanced non-NMDA ion current (McGlade-McCulloh et al., 1993) and the colocalization of CaM-kinase II and GluRs in the PSDs of glutaminergic neurons, the following hypothesis can be formulated. Paradigms such as LTP that result in activation of NMDA ion channels could activate PSD CaM-kinase II with resultant phosphorylation of AMPA-type GluRs. Indeed, it has just been reported that induction of LTP does give stable activation of CaM-kinase II (Fukunaga et al., 1993).

\section{References}

Bading H, Greenberg ME (1991) Stimulation of protein tyrosine phosphorylation by NMDA receptor activation. Science 253:912-914.

Bekkers JM, Stevens CF (1990) Presynaptic mechanism for long-term potentiation in the hippocampus. Nature 346:724-729.

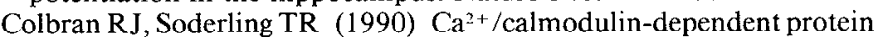
kinase II. Curr Top Cell Regul 31:181-221.

Davies SN, Lester RAJ, Reyman KG, Collingridge GL (1989) Temporally distinct pre- and postsynaptic mechanisms maintain longterm potentiation. Nature 338:500-503.

Egebjerg J, Bettler B, Hermans-Borgmeyer I, Heinemann S (1991) Cloning of a cDNA for a glutamate receptor subunit activated by kainate but not AMPA. Nature 351:745-748.

Erondu NE, Kennedy MB (1985) Regional distribution of type II Ca ${ }^{2+}$ / CaM-dependent protein kinase in rat brain. J Neurosci 5:3270-32\%.

Fuhlbrigge RC, Fine SM, Unanue ER, Chaplin DD (1988) Expression of membrane interleukin 1 by fibroblasts transfected with murine pro-interleukin $1 \alpha$ cDNA. Proc Natl Acad Sci USA 85:5649-5653.

Fukunaga K, Soderling TR (1990) Activation of CaM-kinase II in cerebellar granule cells by NMI)A receptor activation. Mol Cell Neurosci 1:133-138.

Fukunaga K, Rich DP, Soderling TR (1989) Generation of the $\mathrm{Ca}^{2+}-$ independent form of CaM-kinase II in cerebellar granule cells. J Biol Chem 264:21530-21536.

Fukunaga K, Soderling TR, Miyamoto E (1992) Activation of $\mathrm{Ca}^{2+} /$ calmodulin-dependent protein kinase II and protein kinase $C$ by glutamate in cultured rat hippocampal neurons. J Biol Chem 267:2252722533.

Fukunaga K, Stoppini L, Miyamoto E, Muller D (1993) Long-term potentiation is associated with an increased activity of $\mathrm{Ca}^{2+} /$ calmodulin-dependent protein kinase II. J Biol Chem 268:7863-7867.

Gasic GP, Hollmann M (1992) Molecular neurobiology of glutamate receptors. Annu Rev Physiol 54:507-536.

Greengard P, Jen J Nairn AC, Stevens CF (1991) Enhancement of the glutamate response by cAMP-dependent protein kinase in hippocampal neurons. Science 253:1135-1138.

Hanson PI, Schulman H (1992) Neuronal $\mathrm{Ca}^{2+} /$ calmodulin-dependent protein kinases. Annu Rev Biochem 61:559-601.

Hashimoto Y, Soderling TR (1987) Calcium/calmodulin-dependent protein kinase II and calcium/phospholipid-dependent protein kinase activities in rat tissues assayed with a synthetic peptide. Arch Biochem Biophys 252:418-425.

Hidaka H, Kobayoshi K (1992) Pharmacology of protein kinase inhibitors. Annu Rev Pharmacol Toxicol 32:377-397.

Huang FL, Glinsmann W (1976) Separation and characterization of two phosphorylase phosphatase inhibitors from rabbit skeletal muscle. Eur J Biochem 70:419-426.
Keinänen K, Wisden W, Sommer B, Werner P, Herb A, Verdoorn TA, Sakmann B, Seeburg PH (1990) A family of AMPA-selective glutamate receptors. Science 249:556-560.

Keller BU, Hollmann M, Heinemann S, Konnerth A (1992) Calcium influx through subunits GluR1/GluR3 of kainate/AMPA receptor channels is regulated by cAMP dependent protein kinase. EMBO J 11:891-896.

Kennedy MB, Bennett MK, Erondu NG (1983) Biochemical and immunochemical evidence that the "major postsynaptic density protein" is a subunit of a calmodulin-dependent protein kinase. Proc Natl Acad Sci USA 80:7357-7361.

Laemmli VK (1970) Cleavage of structural proteins during the assembly of the head of bacteriophage T4. Nature 227:680-685.

Lester RA, Quarum ML, Parker JD, Weber E, Jahr CE (1989) Interaction of 6-cyano-7-nitroquinoxaline-2,3-dione with the NMDA receptor-associated glycine binding site. Mol Pharmacol 35:565-570.

Lisman J (1989) A mechanism for the Hebb and the anti-Hebb processes underlying learning and memory. Proc Natl Acad Sci USA 86: 9574-9578.

MacNicol M, Schulman H (1992) Cross-talk between protein kinase $\mathrm{C}$ and multifunctional $\mathrm{Ca}^{2+} /$ calmodulin-dependent protein kinase. $\mathbf{J}$ Biol Chem 267:12197-12201.

Madison DV, Malenka RC, Nicoll RA (1991) Mechanisms underlying long-term potentiation of synaptic transmission. Annu Rev Neurosci 14:379-397.

Malinow R, Schulman H, Tsien RW (1989) Inhibition of postsynaptic PKC or CaM-KII blocks induction but not expression of LTP. Science 245:862-866.

McGlade-McCulloh E, Yamamoto H, Tan SE, Brickey DA, Soderling TR (1993) Phosphorylation and regulation of glutamate receptors by calcium/calmodulin-dependent protein kinase II. Nature 362:640642.

Mcllroy BK, Walters JD, Blackshear PJ, Johnson JD (1991) Phosphorylation-dependent binding of a synthetic MARCKS peptide to calmodulin. J Biol Chem 266:4959-4964.

Meffert MK, Parfitt KD, Doze VA, Cohen GA, Madison DV (1991) Protein kinases and long-term potentiation. Ann NY Acad Sci 627: 2-9.

Moss SJ, Blackstone CD, Huganir RL (1993) Phosphorylation of recombinant non-NMDA glutamate receptors on serine and tyrosine residues. Neurochem Res 18:105-110.

Petralia RS, Wenthold RJ (1992) Light and electron immunocytochemical localization of AMPA-selective glutamate receptors in rat brain. J Comp Neurol 318:329-354.

Raymond LA, Blackstone CD, Huganir RL (1993) Phosphorylation and modulation of recombinant GluR6 glutamate receptors by cAMPdependent protein kinase. Nature 361:637-641.

Roskoski R Jr (1985) Protein kinase assay. Methods Enzymol 99:3-6.

Scholz WK, Palfrey HC (1991) Glutamate-stimulated protein phosphorylation in cultured hippocampal pyramidal neurons. J Neurosci 11:2422-2432.

Silva AJ, Stevens CF, Tonegawa S, Wang Y (1992a) Deficient hippocampal long-term potentiation in $\alpha$-calcium-calmodulin kinase II mutant mice. Science 257:201-206.

Silva AJ, Paylor R, Wehner JM, Tonegawa S (1992b) Impaired spatial learning in $\alpha$-calcium-calmodulin kinase II mutant mice. Science 257 : 206-209.

Soderling TR (1993) Calcium/calmodulin-dependent protein kinase II: role in learning and memory. Mol Cell Biochem, in press.

Soderling TR, Corbin JD, Park CR (1973) Regulation of Adenosine 3',5'-monophosphate-dependent protein kinase II: hormonal regulation of the adipose tissue enzyme. J Biol Chem 248:1822-1829.

Tansey MG, Word RA, Hidaka H, Singer HA, Schworer CM, Kamm KE, Stull JT (1992) Phosphorylation of myosin light chain kinase by the multifunctional calmodulin-dependent protein kinase II in smooth muscle cells. J Biol Chem 627:12511-12516.

Wang LY, Salter MW, MacDonald JF (1991) Regulation of kainate receptors by cAMP-dependent protein kinase and phosphatases. Science 253:1132-1138.

Wang LY, Taverna FA, Huang XP, MacDonald JF, Hampson DR (1993) Phosphorylation and modulation of a kainate receptor (GluR6) by cAMP-dependent protein kinase. Science 259:1173-1175.

Wenthold RJ, Yokotani N, Doi K, Wada K (1992) Immunochemical characterization of the non-NMDA glutamate receptor using subunitspecific antibodies. J Biol Chem 267:501-507. 